\title{
Review
}

Neonatology

\section{Lungs, Microbes and the Developing Neonate}

\author{
Barbara B. Warner ${ }^{a}$ Aaron Hamvas ${ }^{a, b}$ \\ ${ }^{a}$ Edward Mallinckrodt Department of Pediatrics, Washington University School of Medicine, St. Louis, Mo., and \\ ${ }^{b}$ Department of Pediatrics, Ann and Robert H. Lurie Children's Hospital of Chicago, Northwestern University \\ Feinberg School of Medicine, Chicago, III., USA
}

\section{Key Words}

Microbiome $\cdot$ Respiratory disease $\cdot$ Newborn .

Bronchopulmonary dysplasia $\cdot$ Asthma $\cdot$ Immune regulation

\begin{abstract}
Microbes are ubiquitous on the human body and comprise approximately $90 \%$ of the cells and $99 \%$ of the genes of the human supraorganism. High-throughput sequencing technology has permitted the development of culture-independent means to identify the microbiota that are unique to the various microenvironments of the body and probably contribute some function. Although the respiratory tract interfaces with the environment, the lungs were always thought to be a sterile environment - until recently, when these techniques were applied to healthy and disease states. Further, there appears to be a complex interplay between the development of the gastrointestinal and respiratory microbiota and the regulation of immune function. The contribution of this dynamic metabolic mass to respiratory disease in the newborn is unknown. This article will review emerging data from recent human and murine studies that suggest there is a microbial influence on the development of respiratory disease, but it will also highlight many of the gaps that remain in understanding the function of the respiratory microbiome.

(c) 2015 S. Karger AG, Basel
\end{abstract}

(c) 2015 S. Karger AG, Base

$1661-7800 / 15 / 1074-0337 \$ 39.50 / 0$

\section{Introduction}

The concept of humans as 'supraorganisms', that is, the eukaryotic human-specific cells and genome as well as the cumulative microbial particles (including bacteria, viruses and fungi), has recently emerged as investigations have identified that the interplay between these microbes and host cells influences health and disease. When considered as a whole, these microbes comprise approximately $90 \%$ of the cells and $99 \%$ of the genes of this supraorganism [1]. The availability of high-throughput sequencing technology has permitted the development of culture-independent means to identify microbes that are present in various microenvironments and are likely to be contributing to some function. The Human Microbiome Project was developed to characterize these microbial communities and better understand their role in human health $[2,3]$. A significant focus has been placed on the intestinal microbiome, not only for ease of accessibility but also for the complex interplay of enteric commensal microorganisms and host health and development. Enteric microorganisms are integral in promoting gastrointestinal (GI) tract development, maintaining intestinal epithelial integrity, harvesting and synthesizing nutrients, and promoting the development of innate and adaptive immunity through a balance of tolerance to luminal

\section{KARGER 125}

E-Mail karger@karger.com

www.karger.com/neo
Aaron Hamvas, MD

Ann and Robert H. Lurie Children's Hospital of Chicago

Northwestern University Feinberg School of Medicine

225 East Chicago Avenue, Box \#45, Chicago, IL 60611 (USA)

E-Mail ahamvas@luriechildrens.org 
Table 1. Common terminology

\begin{tabular}{|c|c|c|}
\hline Microbiome & $\begin{array}{l}\text { The collection of microbes and their collective } \\
\text { genome, located within a specific habitat }\end{array}$ & \\
\hline Microbiota & $\begin{array}{l}\text { The microbial population itself located within a } \\
\text { specific habitat }\end{array}$ & \\
\hline 16S rRNA gene & $\begin{array}{l}\text { Gene that codes for the small ribosomal subunit } \\
\text { (16S) of the prokaryotic ribosome, specific to } \\
\text { bacteria; it consists of regions conserved between } \\
\text { bacteria and hypervariable regions that are unique } \\
\text { and used to identify bacterial species }\end{array}$ & $\begin{array}{l}\text { Amplification and sequence } \\
\text { analysis results in identification of } \\
\text { nucleic acids that are unique to } \\
\text { bacteria }\end{array}$ \\
\hline V1-9 & $\begin{array}{l}9 \text { hypervariable regions of the bacterial } 16 \mathrm{~S} \text { rRNA } \\
\text { gene, often used in combination to identify the taxa } \\
\text { of the bacterial sequence present }\end{array}$ & $\begin{array}{l}\text { Answers the question } \\
\text { 'What is the bacterial composition?' }\end{array}$ \\
\hline Metagenomics & $\begin{array}{l}\text { Sequencing of the entire bacterial chromosome to } \\
\text { identify the genes that are present; provides insight } \\
\text { into a microbial community's functional } \\
\text { characteristics }\end{array}$ & $\begin{array}{l}\text { Answers the question } \\
\text { 'What is the potential for their } \\
\text { activity?' }\end{array}$ \\
\hline $\begin{array}{l}\text { Meta- } \\
\text {-transcriptomics } \\
\text {-proteomics } \\
\text {-metabolomics }\end{array}$ & $\begin{array}{l}\text { Identifies genes being expressed } \\
\text { Identifies proteins being synthesized } \\
\text { Identifies metabolic processes represented }\end{array}$ & $\begin{array}{l}\text { Answers the question } \\
\text { 'What are they actually doing?' }\end{array}$ \\
\hline Dysbiosis & $\begin{array}{l}\text { A state of microbial imbalance, in which the normal } \\
\text { microbial community structure has been perturbed, } \\
\text { resulting often in disease states [16] }\end{array}$ & \\
\hline
\end{tabular}

antigens and recognition of pathogens [for review, see 4]. More recently, the microbial colonization patterns of the airway and more distal lung have been studied in order to understand how these organisms may be playing a role in respiratory disease. In this review we will discuss some of the emerging data about the interactions of the microbiota of the respiratory and intestinal tracts and how they might be related to lung disease of newborn infants and children.

\section{Definitions}

The key terminology used in the field is listed in table 1 and further discussion can be found in a recent review [5]. Most reports to date have been limited to descriptive studies of the taxonomic representation of the microbial genomes present based on sequencing of the variable elements of the bacterial 16s rRNA genes, most commonly either V1-3 or V4-6. However, deeper metagenomic and metatranscriptomic sequencing have provided significant insights into the function of the microbiota and interactions with the host [6-9].

\section{The Respiratory Tract Microbiome}

Previously thought to be sterile, data suggest the presence of bacterial DNA in the lower respiratory tract, some of which is similar to that of the upper airway but some of which appears to be overrepresented in the lower airways [10-12]. Although concerns about acquisition and contamination of lower airway specimens through the necessity of traversing the upper airway in humans are present, careful studies comparing the upper and lower airway microbiota, studies using explanted lungs at the time of transplantation and mouse studies have demonstrated that, although present in low numbers in healthy lungs, there is a lower airway microbial presence that is distinct from that of the upper airway [13-17]. A lingering question remains as to what degree bacterial nucleic acid sequences represent live organisms with the potential to act as pioneering colonizers versus nucleic acid residuals of nonliving organisms.

\section{How Do the Lung Microbiota Get Established?}

While patterns of early intestinal colonization following birth have been well characterized [18-20], the devel- 
Table 2. Classification of bacteria commonly associated with health and disease

\begin{tabular}{|c|c|c|c|c|c|}
\hline & \multicolumn{5}{|l|}{ Phyla } \\
\hline & Actinobacteria & Bacteroidetes & Firmicutes & Proteobacteria & Tenericutes \\
\hline Genus & $\begin{array}{l}\text { Corynebacteria } \\
\text { Bifidobacteria }\end{array}$ & $\begin{array}{l}\text { Prevotella } \\
\text { Bacteroides }\end{array}$ & $\begin{array}{l}\text { Staphylococcus } \\
\text { Streptococcus } \\
\text { Veillonella } \\
\text { Dolosigranulum } \\
\text { Lactobacillus } \\
\text { Enterococcus }\end{array}$ & $\begin{array}{l}\text { Acinetobacter } \\
\text { Haemophilus } \\
\text { Neisseria } \\
\text { Pseudomonas } \\
\text { Moraxella }\end{array}$ & Ureaplasma \\
\hline
\end{tabular}

opment of the lung microbiome, particularly the lower respiratory tract, has just recently been examined. The presence of microbiota within the intact uterine-placental environment raises the possibility of colonization even in utero $[21,22]$. Postnatal exposures also provide significant influences on microbial colonization patterns. Potential sources include the maternal birth canal, infant skin and intestinal tract and environmental microorganisms introduced via inhalation, microaspiration or, in the case of intubated neonates, by direct spread. While the basis of initial colonization of the lung is poorly studied, it is known that the primary determinant of a newborn infant's first microbial community is the mode of delivery $[23,24]$. Infants born vaginally and sampled shortly after birth had microbial communities (skin, oral mucosa, nasopharynx, and intestine) most similar in composition to the vaginal communities of mothers, while those born by cesarean section harbored communities more similar to maternal skin and the environment. To what extent these pioneering microbiota contribute to lung microbiome is unclear for healthy term neonates.

Animal and human studies would also indicate that the lung microbiome undergoes evolution in the first weeks of life, not unlike that reported for the intestines. A recent study in mice demonstrated an increasing bacterial load within the first 2 weeks of life, with a predominance of the phyla Proteobacteria and Firmicutes followed by subsequent expansion of Bacteroidetes with age [25]. Interestingly, a study of 25 preterm infants born at $<32$ weeks of gestation also demonstrated a similar pattern of Proteobacteria (Acinetobacter spp.) and Firmicutes in tracheal aspirates obtained at birth [26]. These results are consistent with other reports that the amniotic fluid is not a sterile environment, even without rupture of membranes [21,27]. Other investigators, however, reported low or undetectable bacterial sequences in tracheal aspirates obtained in the first $72 \mathrm{~h}$ from 10 infants of $<28$ weeks of gestation [28]. In both of these studies of preterm infants though, an evolution of colonization occurred over the first days to weeks of life. In one series, most infants had established a predominant organism by 7 days, either Staphylococcus spp. (Firmicutes) or Ureaplasma spp. (Tenericutes) [28], while in the other series colonization patterns varied by bronchopulmonary dysplasia (BPD) outcome (see Lung Microbiome and Respiratory Disease below) [26].

In contrast, studies of healthy term and older infants rely on accessible upper airway samples. Serial analysis of nasopharyngeal samples from 6 weeks to 2 years demonstrated a characteristic early profile where Staphylococci, Streptococci, Moraxella, Corynebacterium, or Corynebacterium and Dolosigranulum predominated at 6 weeks but by 2 years Moraxella, Streptococci and Haemophilus predominated. Even the pattern of these samples at 2 years differed from those of adults, where Moraxella (Proteobacteria), Dolosigranulum (Firmicutes) and Corynebacterium (Actinobacteria) predominated [29-31].

The adult lung microbiota are primarily represented by the phyla Firmicutes (Streptococcus and Veillonella spp.) and Bacteroidetes (Prevotella spp.), which comprise about $80 \%$ of the species, with lesser representation from Proteobacteria (about 10\%, Pseudomonas, Haemophilus and Neisseria spp.) $[12,13,17,32]$. Exactly when the relative proportions of each microbial class achieve the 'adult' composition is not clear. Table 2 illustrates the classification of bacteria commonly associated with health and disease.

\section{What Are the Lung Microbiota Doing?}

The more interesting question has to do with the functions that these bacteria, and presumably other microbes, are providing in the lung. There is a complex interaction 
between the host cells and microbial cells in all microenvironments of the body. In the case of the lung, epidemiological and experimental evidence suggest a role for local and systemic immune development and regulation (discussed below in The 'Gut-Lung Axis'). Epidemiological observations in the UK suggested a decrease in the prevalence of hay fever with increasing family size, positing the initial 'hygiene hypothesis' [33]. Subsequent studies have not borne out the family size contribution, but children who have been exposed to farm environments, pets and day care exhibit fewer allergies and less asthma, suggesting that early exposure of the airway to allergens or microbial particles may protect against future immunological or microbial insults [34-36]. Thus, interaction of the airway microbiota with cells of the respiratory tract, including epithelial cells, mucus-producing cells or immune effector cells, is likely to influence susceptibility to or protection from disease as well as affect structural development of the lung at critical time points in development $[15,37]$.

\section{Critical Developmental Periods}

The perinatal period is critical for the programing of immune-mediated effects. The importance of microbial exposure during this time period has been elegantly demonstrated in murine models of allergic asthma. Neonatal mice normally demonstrate airway hyperresponsiveness following airway allergen exposure. As the lung bacterial load evolves and increases during development, this hyperresponsiveness decreases. If microbial colonization is, however, limited during the first 2 weeks after birth or if the mice are raised to adulthood under germ-free conditions, hyperresponsiveness to airway challenges is maintained with increased airway resistance, elevated serum and tissue IgE levels and proinflammatory cytokines [38, 39]. These responses have been found to be associated with the accumulation of proinflammatory invariant natural killer cells in both the lungs and the intestines and, in other models, they appear to be mediated through PDL1 (programmed cell death ligand-1) promoting tolerance to aeroallergens $[25,38]$. In the germ-free mice these allergic responses were abrogated only when the mice were recolonized with conventional microbiota through nonorgan-specific environmental exposures early in life. Recolonization as adults had no effect [38].

The role of the lung microbiota has also been specifically evaluated for its impact on lung development. Bacterial communities were present in the lungs of mice raised under specific pathogen-free (SPF) and non-SPF conditions but not in germ-free mice; these communities were more abundant and diverse in non-SPF mice compared with SPF mice. This difference correlated with changes in lung architecture, with the higher bacterial abundance in non-SPF mice correlating with more and smaller alveoli. For confirmation that bacterial colonization was responsible for the observed changes in architecture, germ-free mice were inoculated with bacterial isolates early in life, which induced changes in alveolar architecture similar to those observed in non-SPF mice [15].

It is becoming clear that the lung is exposed to bacterial components very early in life and that the perinatal time period is critical in forming these microbial-host interactions that have an impact on lung development and local and systemic immune responses, many of which are modulated through the GI tract.

\section{The 'Gut-Lung Axis'}

Although interactions between the lung microbiota and respiratory tract cells appear to modulate local immune regulation, development and response, distant interactions with the GI tract may actually be more important in the establishment of local and systemic immune function [40]. Cross-talk between the gut and lung has the potential to exist on multiple levels, from direct physical transfer of bacteria through reflux and microaspiration to indirect effects from their byproducts or mucosa-mediated immune responses common to both the GI tract and the lungs [41]. As described earlier, germ-free mice exhibit more severe allergic airway disease and colitis than conventionally raised animals, an effect that can be mitigated by exposure to conventional environmental conditions and flora early in life [38, 42]. Similar effects have been demonstrated in mice treated with enteral antibiotics $[43,44]$. Animals treated with clinically relevant doses of vancomycin, but not streptomycin, developed more severe asthma, indicating the effect may be more related to microbial composition than numbers. Human epidemiological studies have also linked shifts in intestinal microbial communities to allergic and asthmatic manifestations [45-47].

The gut microbiota may also affect respiratory function through metabolic by-products such as short-chain fatty acids (SCFA). Mice fed a high-fiber diet had increased proportions of Bacteroidetes in the GI tract and higher circulating SCFA. These animals were protected from allergic airway inflammation, whereas animals fed low-fiber diets had increased proportions of Firmicutes, decreased circulating SCFA and increased allergic air- 
way disease [48]. SCFA also resulted in bone marrowderived lung dendritic cells that were less capable of driving TH2 cell responses, thus mitigating airway inflammation.

In humans, breast milk feeding affects the composition of both the respiratory and GI tract microbiota, further suggesting a link between the lung and the gut [2931]. Further, serial sampling of respiratory and stool samples in infants with cystic fibrosis demonstrated that, while the microbial communities at the two sites had distinct compositions, there was an overlapping core dominated by Veillonella and Streptococcus, with a high degree of concordance between bacteria that were increasing and decreasing over time in both compartments. Additionally, dietary changes affected the airway microbial composition, suggesting a link between nutrition and the respiratory flora [49].

Thus, the GI tract appears to play a key role in immune development and regulation, some of which may be mediated by nutritional factors which, in turn, affect respiratory health and responses to environmental exposures.

\section{Lung Microbiome and Respiratory Disease}

Recent studies have started to evaluate the relationship between the airway microbiome and respiratory disease in order to understand its role in the mechanisms or modification thereof and to expand the possibilities for therapeutic intervention. In contrast to studies focusing on the GI tract where the metagenomics have been evaluated, human lung studies have been primarily limited to descriptive measures of composition, abundance and diversity measures.

\section{Asthma}

The strong interactions between the microbiota and immune responses have led to the natural focus on asthma and allergic disease. Studies utilizing bronchoalveolar lavage or induced sputum have demonstrated that Proteobacteria (predominantly Haemophilus spp.) are more abundant in distal airways of individuals with asthma and chronic obstructive pulmonary disease (COPD); Firmicutes (Staphylococcus spp.) are more abundant in children with difficult asthma [17, 50, 51]. In contrast, Bacteroidetes, especially Prevotella spp., are more abundant in controls [50]. Further suggesting a role for these bacteria in disease are observations from murine and cell-based studies that demonstrated enhanced TLR-2 (Toll-like receptor 2)-independent inflammation for asthma and
COPD-associated Proteobacteria (Haemophilus spp. and Moraxella) compared with commensals Prevotella spp., which exhibit weak, TLR-2-dependent inflammatory properties [52].

\section{Idiopathic Pulmonary Fibrosis}

In comparison with healthy individuals who did or did not smoke and individuals with COPD, individuals with idiopathic pulmonary fibrosis (IPF) had double the bacterial load in their bronchoalveolar lavage fluid and higher bacterial load was associated with more progressive disease $[53,54]$. Specific species of Firmicutes (Veillonella and Streptococcus) and Proteobacteria (Neisseria) were also associated with IPF after controlling for age and smoking. In addition, the presence of the mucin $5 \mathrm{~B}$ gene promoter variant minor allele (rs35705950), which is more prevalent in individuals with IPF but is associated with slower progression of disease [55], was also associated with lower bacterial burden, raising an interesting speculation about interactions between this genetic variant, the burden of bacterial colonization and progression of disease [53]. In contrast, no evidence for microbial dysbiosis was identified in a small group of individuals with non-IPF interstitial pneumonias [56].

\section{Chronic Obstructive Pulmonary Disease}

As described, many studies have used individuals with COPD as disease controls. The COPD lung resembles that of the asthmatic lung in terms of relative microbial representation, with Proteobacteria and Firmicutes (predominantly Staphylococci and Streptococci) being abundant $[13,17,57]$.

\section{Bronchopulmonary Dysplasia}

Whether or not the microbiome plays a direct role in the pathogenesis of BPD has just begun to be explored. Microbial elements, primarily Acinetobacter, could be identified in tracheal aspirates of infants born at $<28$ weeks of gestation, even with cesarean delivery. Those who later developed BPD demonstrated decreasing bacterial diversity, decreasing proportions of Acinetobacter spp. and increasing proportions of Staphylococcus spp. in tracheal aspirates over the first 3 weeks. Despite these changes in bacterial composition, there was no correlation with inflammatory cytokines, leaving the question of functional importance open [25]. In the study of Mourani et al. [28] of a group of infants at risk for BPD, the identification of Ureaplasma spp. as early as 7 days supports past studies suggesting that Ureaplasma is a risk factor for the development of BPD $[58,59]$. 


\section{Key Questions and Opportunities}

While these human studies have just begun to identify differences in the microbial composition of the upper and lower airways in respiratory health and disease, the functional importance of these differences, if any, remain to be elucidated. Understanding the composition and diversity of this microbiome only touches the surface of the following more important issues: do the specific microbiota influence or modify the type of disease or does the disease environment permit a specific microbial outgrowth? What genes are being expressed by these organisms, what functions are they providing and how are they interacting with unique cell types, the environment and the host's genome within the different areas of the lung? Applying newly developing high-throughput 'omics' approaches will provide some insight into these issues. The challenge for lung disease remains access to the airway, so it will be necessary to identify other more accessible sources that might mimic the respiratory microbiome and can be used as proxies for the distal airway. Finally, the apparent cross-talk between the immune system of the gut and systemic immune regulation that appears to be determined in early life suggests opportunities for intervention and early prevention.

\section{Acknowledgments}

This work was supported in part by grants NIH U01 HL101465 and NIH/NIAID/NICHD UH3 AI083265 and by the Children's Discovery Institute of Washington University in St. Louis (MDII-2011-127).

\section{Disclosure Statement}

The authors do not receive support from any commercial interests and have no conflict of interest to declare.

\section{References}

$>1$ Bäckhed F, Ley RE, Sonnenburg JL, Peterson DA, Gordon JI: Host-bacterial mutualism in the human intestine. Science 2005;307:1915 1920.

>2 NIH HMP Working Group; Peterson J, Garges S, Giovanni M, McInnes P, Wang L, et al: The NIH human microbiome project. Genome Res 2009;19:2317-2323.

$>3$ Turnbaugh PJ, Ley RE, Hamady M, FraserLiggett CM, Knight R, Gordon JI: The human microbiome project. Nature 2007;449:804810.

4 Sommer F, Backhed F: The gut microbiotamasters of host development and physiology. Nat Rev Microbiol 2013;11:227-238.

$\checkmark 5$ Sherman MP, Minnerly J, Curtiss W, Rangwala S, Kelley ST: Research on neonatal microbiomes: what neonatologists need to know. Neonatology 2014;105:14-24.

-6 Waldor MK, Tyson G, Borenstein E, Ochman H, Moeller A, Finlay BB, et al: Where next for microbiome research? PLoS Biology 2015; 13:e1002050.

$>7$ Kau AL, Ahern PP, Griffin NW, Goodman $\mathrm{AL}$, Gordon JI: Human nutrition, the gut microbiome and the immune system. Nature 2011;474:327-236.

$>8$ Muegge BD, Kuczynski J, Knights D, Clemente JC, Gonzalez A, Fontana L, et al: Diet drives convergence in gut microbiome functions across mammalian phylogeny and within humans. Science 2011;332:970-974.

$>9$ Turnbaugh PJ, Ley RE, Mahowald MA, Magrini V, Mardis ER, Gordon JI: An obesityassociated gut microbiome with increased ca- pacity for energy harvest. Nature 2006;444: 1027-1031.

-10 Segal LN, Rom WN, Weiden MD: Lung microbiome for clinicians. New discoveries about bugs in healthy and diseased lungs. Ann Am Thorac Soc 2014;11:108-116.

$\checkmark 11$ Charlson ES, Bittinger K, Chen J, Diamond JM, Li H, Collman RG, et al: Assessing bacterial populations in the lung by replicate analysis of samples from the upper and lower respiratory tracts. PLoS One 2012;7:e42786.

12 Morris A, Beck JM, Schloss PD, Campbell TB, Crothers K, Curtis JL, et al: Comparison of the respiratory microbiome in healthy nonsmokers and smokers. Am J Respir Crit Care Med 2013;187:1067-1075.

13 Erb-Downward JR, Thompson DL, Han MK, Freeman CM, McCloskey L, Schmidt LA, et al: Analysis of the lung microbiome in the 'healthy' smoker and in COPD. PLoS One 2011;6:e16384.

14 Goddard AF, Staudinger BJ, Dowd SE, JoshiDatar A, Wolcott RD, Aitken ML, et al: Direct sampling of cystic fibrosis lungs indicates that DNA-based analyses of upper-airway specimens can misrepresent lung microbiota. Proc Natl Acad Sci USA 2012;109:13769-13774.

15 Yun Y, Srinivas G, Kuenzel S, Linnenbrink M, Alnahas S, Bruce KD, et al: Environmentally determined differences in the murine lung microbiota and their relation to alveolar architecture. PLoS One 2014;9:e113466.

16 Zemanick ET, Wagner BD, Robertson CE, Stevens MJ, Szefler SJ, Accurso FJ, et al: Assessment of airway microbiota and inflamma- tion in cystic fibrosis using multiple sampling methods. Ann Am Thorac Soc 2015;12:221229.

17 Marsland BJ, Gollwitzer ES: Host-microorganism interactions in lung diseases. Nat Rev Immunol 2014;14:827-835.

18 La Rosa PS, Warner BB, Zhou Y, Weinstock GM, Sodergren E, Hall-Moore CM, et al: Patterned progression of bacterial populations in the premature infant gut. Proc Natl Acad Sci USA 2014;111:12522-12527.

19 Yatsunenko T, Rey FE, Manary MJ, Trehan I, Dominguez-Bello MG, Contreras $\mathrm{M}$, et al: Human gut microbiome viewed across age and geography. Nature 2012;486:222-227.

20 Palmer C, Bik EM, DiGiulio DB, Relman DA, Brown PO: Development of the human infant intestinal microbiota. PLoS Biol 2007;5:e177.

21 Aagaard K, Ma J, Antony KM, Ganu R, Petrosino J, Versalovic J: The placenta harbors a unique microbiome. Science Transl Med 2014;6:237ra65.

22 Cao B, Stout MJ, Lee I, Mysorekar I: Placental microbiome and its role in preterm birth. Neoreviews 2014;15:e537-545.

23 Dominguez-Bello MG, Costello EK, Contreras M, Magris M, Hidalgo G, Fierer N, et al: Delivery mode shapes the acquisition and structure of the initial microbiota across multiple body habitats in newborns. Proc Natl Acad Sci USA 2010;107:11971-11975.

-24 Biasucci G, Benenati B, Morelli L, Bessi E, Boehm G: Cesarean delivery may affect the early biodiversity of intestinal bacteria. J Nutr 2008; 138:1796S-1800S. 
25 Gollwitzer ES, Saglani S, Trompette A, Yadava K, Sherburn R, McCoy KD, et al: Lung microbiota promotes tolerance to allergens in neonates via PD-L1. Nat Med 2014;20:642647.

26 Lohmann P, Luna RA, Hollister EB, Devaraj S, Mistretta TA, Welty SE, et al: The airway microbiome of intubated premature infants: characteristics and changes that predict the development of bronchopulmonary dysplasia. Pediatr Res 2014;76:294-301.

27 DiGiulio DB, Romero R, Amogan HP, Kusanovic JP, Bik EM, Gotsch F, et al: Microbial prevalence, diversity and abundance in amniotic fluid during preterm labor: a molecular and culture-based investigation. PLoS One 2008;3:e3056.

28 Mourani PM, Harris JK, Sontag MK, Robertson CE, Abman SH: Molecular identification of bacteria in tracheal aspirate fluid from mechanically ventilated preterm infants. PLoS One 2011;6:e25959.

29 Biesbroek G, Bosch AA, Wang X, Keijser BJ, Veenhoven RH, Sanders EA, et al: The impact of breastfeeding on nasopharyngeal microbial communities in infants. Am J Respir Crit Care Med 2014;190:298-308.

- 30 Biesbroek G, Tsivtsivadze E, Sanders EA, Montijn R, Veenhoven RH, Keijser BJ, et al: Early respiratory microbiota composition determines bacterial succession patterns and respiratory health in children. Am J Respir Crit Care Med 2014;190:1283-1292.

- 31 Yan M, Pamp SJ, Fukuyama J, Hwang PH, Cho DY, Holmes S, et al: Nasal microenvironments and interspecific interactions influence nasal microbiota complexity and $S$. aureus carriage. Cell Host Microbe 2013;14:631-640.

-32 Charlson ES, Bittinger K, Haas AR, Fitzgerald AS, Frank I, Yadav A, et al: Topographical continuity of bacterial populations in the healthy human respiratory tract. Am J Respir Crit Care Med 2011;184:957-963.

-33 Strachan DP: Hay fever, hygiene, and household size. BMJ 1989;299:1259-1260.

-34 Strachan DP: Family size, infection and atopy: the first decade of the 'hygiene hypothesis'. Thorax 2000;55(suppl 1):S2-S10.

-35 Ege MJ, Mayer M, Normand AC, Genuneit J, Cookson WO, Braun-Fahrlander C, et al: Exposure to environmental microorganisms and childhood asthma. N Engl J Med 2011; 364:701-709.

- 36 Maier RM, Palmer MW, Andersen GL, Halonen MJ, Josephson KC, Maier RS, et al: Environmental determinants of and impact on childhood asthma by the bacterial community in household dust. Appl Environ Microbiol 2010;76:2663-2667.
37 Gollwitzer ES, Marsland BJ: Microbiota abnormalities in inflammatory airway diseases - potential for therapy. Pharmacol Ther 2014;141:32-39.

-38 Olszak T, An D, Zeissig S, Vera MP, Richter J, Franke A, et al: Microbial exposure during early life has persistent effects on natural killer T cell function. Science 2012;336:489-493.

39 Cahenzli J, Koller Y, Wyss M, Geuking MB, McCoy KD: Intestinal microbial diversity during early-life colonization shapes longterm IgE levels. Cell Host Microbe 2013;14: 559-570.

40 Hooper LV, Littman DR, Macpherson AJ: Interactions between the microbiota and the immune system. Science 2012;336:12681273.

41 Gill N, Wlodarska M, Finlay BB: The future of mucosal immunology: studying an integrated system-wide organ. Nat Immunol 2010;11: 558-560.

$\checkmark 42$ Herbst T, Sichelstiel A, Schar C, Yadava K, Burki K, Cahenzli J, et al: Dysregulation of allergic airway inflammation in the absence of microbial colonization. Am J Respir Crit Care Med 2011;184:198-205.

43 Hill DA, Siracusa MC, Abt MC, Kim BS, Kobuley D, Kubo M, et al: Commensal bacteriaderived signals regulate basophil hematopoiesis and allergic inflammation. Nat Med 2012; 18:538-546.

44 Russell SL, Gold MJ, Hartmann M, Willing BP, Thorson L, Wlodarska M, et al: Early life antibiotic-driven changes in microbiota enhance susceptibility to allergic asthma. EMBO Rep 2012;13:440-447.

45 Bjorksten B, Naaber P, Sepp E, Mikelsaar M: The intestinal microflora in allergic Estonian and Swedish 2-year-old children. Clin Exp Allergy 1999;29:342-346.

46 Ouwehand AC, Isolauri E, He F, Hashimoto $\mathrm{H}$, Benno Y, Salminen S: Differences in Bifidobacterium flora composition in allergic and healthy infants. J Allergy Clin Immunol 2001; 108:144-145.

47 van Nimwegen FA, Penders J, Stobberingh EE, Postma DS, Koppelman GH, Kerkhof M, et al: Mode and place of delivery, gastrointestinal microbiota, and their influence on asthma and atopy. J Allergy Clin Immunol 2011; 128:948-955.e1-e3.

48 Trompette A, Gollwitzer ES, Yadava K, Sichelstiel AK, Sprenger N, Ngom-Bru C, et al: Gut microbiota metabolism of dietary fiber influences allergic airway disease and hematopoiesis. Nat Med 2014;20:159-166.
49 Madan JC, Koestler DC, Stanton BA, Davidson L, Moulton LA, Housman ML, et al: Serial analysis of the gut and respiratory microbiome in cystic fibrosis in infancy: interaction between intestinal and respiratory tracts and impact of nutritional exposures. MBio 2012; 3:e00251-12.

50 Hilty M, Burke C, Pedro H, Cardenas P, Bush A, Bossley C, et al: Disordered microbial communities in asthmatic airways. PLoS One 2010;5:e8578.

51 Marri PR, Stern DA, Wright AL, Billheimer D, Martinez FD: Asthma-associated differences in microbial composition of induced sputum. J Allergy Clin Immunol 2013;131: 346-352. e1-e3.

52 Larsen JM, Musavian HS, Butt TM, Ingvorsen C, Thysen AH, Brix S: Chronic obstructive pulmonary disease and asthma-associated Proteobacteria, but not commensal Prevotella spp., promote Toll-like receptor 2-independent lung inflammation and pathology. Immunology 2015;144:333-342.

53 Molyneaux PL, Cox MJ, Willis-Owen SA Mallia P, Russell KE, Russell AM, et al: The role of bacteria in the pathogenesis and progression of idiopathic pulmonary fibrosis. Am J Respir Crit Care Med 2014;190:906913.

54 Han MK, Zhou Y, Murray S, Tayob N, Noth I, Lama VN, et al: Lung microbiome and disease progression in idiopathic pulmonary fibrosis: an analysis of the COMET study. Lancet Respir Med 2014;2:548-556.

55 Seibold MA, Wise AL, Speer MC, Steele MP, Brown KK, Loyd JE, et al: A common MUC5B promoter polymorphism and pulmonary fibrosis. N Engl J Med 2011;364:1503-1512.

- 56 Garzoni C, Brugger SD, Qi W, Wasmer S, Cusini A, Dumont P, et al: Microbial communities in the respiratory tract of patients with interstitial lung disease. Thorax 2013;68: 1150-1156.

57 Sze MA, Dimitriu PA, Hayashi S, Elliott WM, McDonough JE, Gosselink JV, et al: The lung tissue microbiome in chronic obstructive pulmonary disease. Am J Respir Crit Care Med 2012;185:1073-1080.

58 Da Silva O, Gregson D, Hammerberg O: Role of Ureaplasma urealyticum and chlamydia trachomatis in development of bronchopulmonary dysplasia in very low birth weight infants. Pediatr Infect Dis J 1997;16:364-369.

59 van Waarde WM, Brus F, Okken A, Kimpen $\mathrm{JL}$ : Ureaplasma urealyticum colonization, prematurity and bronchopulmonary dysplasia. Eur Respir J 1997;10:886-890. 